\title{
La elite judeoconversa de la Corte de los Reyes Católicos y el negocio fiscal
}

\section{The Converso Elite in the Court of the Catholic Monarchs and Fiscal Affairs}

\author{
María del Pilar RÁBADE OBRAdó \\ Universidad Complutense. Madrid \\ mprabade@ucm.es
}

\section{RESUMEN}

Este trabajo trata de ofrecer algunas claves para entender la participación de los judeoconversos en el negocio fiscal en la Castilla de los Reyes Católicos. Para ello, se ofrece una visión sintética de la trayectoria de dos de los financieros judeoconversos más vinculados con los soberanos, Fernán Pérez Coronel y Fernán Núñez Coronel.

Palabras clave: Castilla, Siglo XV, Reyes Católicos, Judeoconversos, Negocio fiscal.

\begin{abstract}
This study analyses the participation of Conversos of Jewish descent in the fiscal affairs of the Catholic Monarchs in Castile. A synthesis will be made of the careers of two of the most prominent Converso financiers linked with these monarchs, Fernán Pérez Coronel and Fernán Núñez Coronel.
\end{abstract}

Key words: Castile, Fifteenth Century, Catholic Monarchs, Conversos, Fiscal Affairs.

Sumario: 1. De los arrendadores de rentas judíos a los judeoconversos. 2. La actuación de los judeoconversos como arrendadores de rentas: algunos ejemplos. 3. Elites judeoconversas y arrendamiento de rentas: el caso de los Coronel. 4. Conclusiones.

Se convirtieron a la fe católica muchos millares de judíos, los quales antes que se fuesen eran muy ricos, porque solo un judío dellos arrendava la mesa de Castilla, e todos eran arrendadores de los maestrazgos, de las encomiendas, de los pueblos de los señores, e los que no alcançavan a tanto eran ofiçiales de ofiçios holgados, sin que nenguno de ellos cavase, arase ni travajase en ofiçio pesado, e aunque quando tornaron vinieron robados de las tierras agenas, e pobres ellos, se tornaron a rehazer en pocos días; porque como entre ellos hay poca vergüenza y ninguna conçiençia no teniendo

${ }^{1}$ Este trabajo se ha elaborado dentro del Proyecto de Investigación de la Secretaría de Estado de Investigación HAR2010-16762. 
mayor fin que el interés, disimulando su mala cristiandad y usando claramente de su codiçia y logros, presto se tornaron a hazer ricos; y los que lo son, son más sobervios y anbiçiosos que otra naçión del mundo, porque el judío con nesçesidad del christiano bésale los pies; y si el christiano tiene nesçesidad del saltale en la cabeça.

Estas palabras, entresacadas de las Ilustraciones de la Casa de Niebla de Pedro Barrantes Maldonado ${ }^{2}$, aunque referidas en principio a los judíos, permiten trazar con claridad una línea continua que nos lleva de aquéllos a los judeoconversos. Estos se convirtieron en sus herederos, y, así, heredaron no sólo sus supuestas riquezas y sus "ofiçios holgados", si no también (según opinión muy generalizada) su doblez en el trato con los cristianos viejos, $\mathrm{y}$, en consecuencia, la hostilidad de estos.

Entre esos "ofiçios holgados", el de arrendador de rentas. En efecto, si ya los judíos lo habían ejercido de forma habitual desde la Plena Edad Media, convirtiéndose los arrendadores hebreos en parte del paisaje habitual en el que se desarrollaban las vidas de sus coetáneos cristianos ${ }^{3}$, lo mismo sucedió, ya en los momentos postreros del Medievo, con los arrendadores de rentas judeoconversos ${ }^{4}$. Estos siguieron la tradición de sus ancestros judíos, y, como ellos, desempeñaron un oficio que contribuyó en no poca medida a excitar contra ellos los odios y los rencores de los cristianos viejos ${ }^{5}$. Pero cierto es también que esa evidente desventaja se vio paliada por los muchos beneficios que derivaban del ejercicio del oficio; entre ellos, las posibilidades de enriquecimiento que suponía ${ }^{6}$, pero también la posibilidad de ascender socialmente.

Así, no resulta en absoluto extraño que durante el reinado de los Reyes Católicos existieran importantes vínculos entre las elites judeoconversas y los arrendadores de rentas de ese origen. Al fin y al cabo, "los arrendadores no eran simples técnicos expertos en fiscalidad, si no individuos que trataban de hacerse un lugar en la corte y adquirir influencia"7. Por otra parte, también "eran individuos con gran amplitud de horizontes, que aunque tuvieron una fuerte vinculación política y afectiva con su ciudad de avecindamiento, estaban relacionados con hombres de negocios de los ámbitos geográficos más diversos". Finalmente, no podemos olvidar que "la Hacienda no ha sido un medio más del Estado, si no fundamento muy principal de su

2 Barrantes Maldonado, P.: Ilustraciones de la Casa de Niebla, Cádiz, 1998, p. 397.

3 Situación que resalta Ladero Quesada, M. A.: La hacienda real de Castilla en el siglo XV, La Laguna, 1973, pp. 27-28.

${ }^{4}$ Aunque en Ibidem, p. 28, se afirma que los judeoconversos tuvieron en el arrendamiento de rentas una participación menor que los judíos.

5 Ibidem, p. 22: "entre la hacienda y los contribuyentes se erguía la figura de un intermediario que gestionaba el cobro porque contaba, o pretendía contar, con los instrumentos adecuados para ello", en el contexto de un sistema que implicaba de manera muy frecuente el abuso y la corrupción, con numerosos "defectos y motivos de crítica"; sin olvidar, por supuesto, que "a los contribuyentes nunca les interesó tributar para nadie, salvo por obligación o por haber llegado, cosa bastante rara, al convencimiento de que debían hacerlo" (p. 29).

${ }^{6}$ Aunque cierto es también que para arrendar rentas habían de ser, como se recuerda en Ibidem, p. 25 "verdaderos capitalistas, dueños del dinero".

7 Diago Hernando, M.: “Arrendadores arandinos al servicio de los Reyes Católicos", Historia. Instituciones. Documentos (Sevilla) 18 (1991) 71-95 y en concreto p. 77.

${ }^{8}$ Ibidem, p. 81. 
acción", de tal forma que "el dominio hacendístico hace posible el político", lo que confería a los arrendadores un papel aún más relevante.

Este estudio pretende ofrecer una primera aproximación de conjunto a la realidad de esos arrendadores judeoconversos que desarrollaron su actividad durante el reinado de los Reyes Católicos, aún a sabiendas de que es mucho el trabajo que queda por hacer, habida cuenta del estado actual de nuestros conocimientos sobre el tema ${ }^{10}$.

\section{DE LOS ARRENDADORES DE RENTAS JUDÍOS A LOS JUDEOCONVERSOS}

Desde que en la Corona de Castilla se hizo evidente que el procedimiento más sencillo y práctico para recaudar impuestos (como indica Ladero, sobre todo "el procedimiento de gestión más rentable" "11, también "el único capaz de garantizar al rey unos ingresos adecuados y de movilizar las fuerzas financieras necesarias y dispuestas a correr los riesgos de la operación" ${ }^{12}$ ) era el de su arrendamiento en pública subasta, los cristianos tuvieron que acostumbrarse al hecho de que los arrendadores eran, en número importante, judíos. Este procedimiento se impuso a partir del reinado de Alfonso X el Sabio: ya en las Siete Partidas se indicaba que las rentas y derechos del rey tendrían que arrendarse en pública subasta, de acuerdo con una serie de condiciones que se especificaban ${ }^{13}$. Sus ventajas eran evidentes, pues no sólo resultaba el procedimiento menos oneroso para la Corona, si no que también "permitía atraer un flujo importante y continuo de capital financiero, vinculándolo a los designios políticos de la Corona"; esto, "a pesar de que una parte notable [...] del producto tributario pasaba a poder de los arrendadores". En cualquier caso, era el mejor sistema, como demuestra el hecho de que continuara vigente más allá del fin del Medievo ${ }^{14}$.

Entre los arrendadores de rentas se contaron "ricos hombres, caballeros, e incluso algunos clérigos", que se convirtieron en tales impulsados por "motivaciones políticas de incremento o ejercicio de su poder", pero también por "la inseguridad en el cobro de tierras, sueldos, mercedes y otras cantidades que tenían asignadas con cargo a la hacienda real sobre las rentas de tal o cual partido o concepto fiscal"15. Pero junto a los cristianos destacaron desde el primer momento (tanto cuantitativa

${ }^{9}$ Ladero Quesada, M. A., La hacienda..., p. 9.

${ }^{10}$ Ibidem, p. 71: "no hay duda de que la historia de los financieros castellanos que trabajaron al servicio de la monarquía en los siglos bajomedievales está todavía por hacer, pese a que algunos autores ya han realizado pequeñas afirmaciones". Este autor insiste, además, en la necesidad de proceder a la realización de estudios de historia local, que considera que son esenciales para hacer avanzar nuestros conocimientos sobre el tema.

${ }^{11}$ Ladero Quesada, M. A.: "Estado y hacienda en Castilla durante la Baja Edad Media", en B. BenNassar et al.: Estado, hacienda y sociedad en la historia de España, Valladolid, 1989, pp. 11-43, concretamente p. 35.

${ }^{12}$ Ladero Quesada, M. A.: La hacienda ..., p. 30.

${ }^{13}$ Ladero Quesada, M. A.: Fiscalidad y poder real en Castilla (1252-1369), Madrid, 1993, p. 255.

${ }^{14}$ Ladero Quesada, M. A.: "Estado y hacienda...., p. 35

${ }^{15}$ Ladero Quesada, M. A.: Fiscalidad y poder real..., p. 256. 
como cualitativamente) los arrendadores judíos, aunque cierto es también que las circunstancias pueden contribuir a que se les atribuya un papel excesivo ${ }^{16}$. En efecto, no se puede olvidar que "por mucha que fuese la importancia de aquellos financieros y arrendadores judíos, pertenecían todos a varios círculos familiares o de relación profesional muy restringidos en relación con el conjunto mismo de la comunidad judía"17.

Cabe preguntarse los motivos que llevaron a algunos judíos a "especializarse" en el arrendamiento de rentas. Evidentemente, entre esos motivos deben estar los arraigados prejuicios que muchos cristianos sentían hacía aquéllos que "comerciaban" con el dinero ${ }^{18}$, enriqueciéndose de una forma que muchos consideraban ilícita, o al menos poco respetable. En efecto, y siguiendo a Aristóteles, se consideraba que el dinero era algo improductivo, "un símbolo o un medio de cambio, pero no como una mercancía equivalente a un bien real o natural (cosas que, con razón, se consideraban virtualmente productivas)" "19. Aunque esos prejuicios estaban, ya en el siglo XIII, en vías de desaparición, o al menos de moderación, lo cierto es que todavía existían, y tal vez pudieron contribuir a empujar a muchos judíos a ejercer un oficio que los cristianos no siempre estaban bien dispuestos a desempeñar.

Además, el arrendador de rentas había de disponer de una cierta masa de capital líquido, pues sólo así podía hacer frente al desempeño de su oficio, y los miembros de la elite judía solían cumplir tal condición. Para ellos, el disponer de una cierta masa de capital líquido era algo realmente crucial: se trataba de "riqueza fácilmente transportable o susceptible de ser escondida en momentos difíciles"20; por tanto, se trataba de una riqueza que podía ser conservada incluso en las peores circunstancias, como era el caso, no impensable, de una expulsión.

Finalmente, cuando se convertían en arrendadores de rentas los judíos ejercían un oficio que a los cristianos no les atraía demasiado, por las implicaciones que tenía, pero que resultaba esencial para la vida económica del momento. Así, igual que cuando desempeñaban oficios que implicaban una formación específica no demasiado

${ }^{16}$ Ibidem, p. 258. Ver también Ladero Quesada, M. A.: "Los judíos castellanos del siglo XV en el arrendamiento de impuestos reales", Cuadernos de Historia. Anexos de Hispania (Madrid) 6 (1975) 417-439. De todas formas, la relevancia de su actividad como arrendadores de rentas queda demostrada si se recuerda que la expulsión de los judíos en 1492, unida, todo hay que decirlo, a las consecuencias de la actividad inquisitorial, supuso una importante crisis del sistema de arrendamiento, de acuerdo con Ladero Quesada, M. A.: La hacienda..., p. 31.

${ }^{17}$ Ibidem, p. 261.

18 Ya Le Goff, J.: La civilización del Occidente Medieval, Barcelona, 1969, p. 341, señaló la "desconfianza tradicional con respecto al dinero" que había marcado al cristianismo desde sus inicios. Ver, asimismo, Le Goff, J.: La bolsa y la vida: economía y religión en la Edad Media, Barcelona, 1987, así como Little, L. K.: Pobreza voluntaria y economía de beneficio en la Europa Medieval, Madrid, 1989, en especial 34-81.

${ }^{19}$ Knowles, M. D. (dir.): Nueva historia de la Iglesia. II: la Iglesia en la Edad Media, Madrid, 1977, p. 384 .

${ }^{20}$ Monsalvo Antón, J. M.: Teoría y evolución de un conflicto social: el antisemitimo en la Corona de Castilla durante la Baja Edad Media, Madrid, 1985, p. 66. 
habitual (el caso de los médicos), los judíos se convertían en piezas imprescindibles para la sociedad cristiana, que necesitaba de su presencia ${ }^{21}$.

Así, se puede afirmar que los judíos que se consagraron al arrendamiento de rentas lo hicieron fundamentalmente como consecuencia de su situación de marginalidad, como consecuencia, también, de la necesidad de asegurar su posición en un medio hostil. De alguna forma, "los judíos son empujados [...] hacia un tipo determinado de actividades económicas [...] el status que le concede al judío la comunidad mayoritaria le convierte en individuo 'apto' para el ejercicio de ciertas profesiones, y esto al margen de la propia 'voluntad' o 'manera de ser' de los judíos"22.

La actividad de los arrendadores de rentas judíos no contribuyó, precisamente, a mejorar la popularidad de los hebreos entre los cristianos, como demuestra la frecuencia con la que, a partir de ese momento, se acusó a los judíos de exprimir, literalmente, a los cuitados cristianos ${ }^{23}$; los recaudadores judíos les tratarían con una dureza extrema, determinada no sólo por su afán de enriquecimiento, si no también por el odio visceral que sentían hacia ellos. Estas ideas estuvieron ya presentes durante el reinado de Alfonso X el Sabio, y adquirieron un auténtico cauce de expresión en los Cuadernos de Cortes $^{24}$, reflejándose, asimismo, en muchas de las fuentes narrativas del momento ${ }^{25}$.

Además, el hecho de que parte de los gestores de la hacienda regia (sobre todo, los almojarifes mayores) fueran frecuentemente judíos permitía deducir que los arrendadores hebreos estaban inmersos en "un complejo de intereses financieros en

${ }^{21}$ Véase, por ejemplo, cómo Valdeón Baruque, J.: Los conflicto sociales en el Reino de Castilla en los siglos XIV y XV, Madrid, 1975, p. 77 señala que no es casualidad que unos judíos segregados desempeñaran habitualmente tanto oficios de índole financiera como aquellos otros "para los que era preciso tener unos conocimientos especiales (médicos, traductores)".

${ }^{22}$ Monsalvo Antón, J. M.: Teoría y evolución..., p. 67. Como afirma Ladero Quesada, M. A.: "Crédito y comercio de dinero en la Castilla medieval", Acta histórica et Archaeologica Mediaevalia (Barcelona) 11-12 (1990-1991) 145-159, concretamente p. 146, se "dejaba el protagonismo de parte de la actividad mercantil y financiera -no toda- a sectores sociales externos o marginales".

${ }^{23}$ Recuérdese el bien conocido (y abundantemente citado, por ejemplo en VALDEÓN BARUQUE, J.: Judios y conversos en la Castilla Medieval, Valladolid, 2000, pp. 73-74, así como Mitre Fernández, E.: Los judios de Castilla en tiempo de Enrique III: el pogrom de 1391, Valladolid, 1993, pp. 130-131) pasaje del Rimado de Palacio de Pedro López de Ayala en el que se plantea con tintas especialmente negras la actividad de los arrendadores judíos: "allí vienen judíos, que están aparejados/ para beber la sangre de los pobres cuytados;/ presentan sus escriptos que tienen concertados,/ e prometen sus joyas e dones a privados.../ Allí fasen judíos el su repartimiento/ sobre el pueblo que muere por mal defendimiento,/ e ellos entre sí partan luego medio cuento/ que han de aver privados, qual ochenta qual çiento.../ Disen luego al rey: por çierto nos tenedes/ judíos servidores, e merced les haredes,/ ca vos pujan la renta por çima las paredes,/ otorgádgelas, señor, que buen recabdo avredes./ Señor, disen judíos, serviçio vos faremos,/ tres cuentos más que antaño por ellas vos daremos,/ e buenos fiadores llanos vos prometemos,/ con estas condiçiones que escriptas vos tenemos./ Aquellas condiciones Dios sabe quales son,/ para el pueblo mesquino negras como carbón".

${ }^{24}$ Recoge diversos testimonios en este sentido Ladero Quesada, M. A.: Fiscalidad y poder real..., pp. 261 y ss.

${ }^{25}$ Se ha de tener presente, una vez más, el Rimado de Palacio; aparte de los versos ya resaltados más arriba, se puede añadir alguno más, igualmente significativo; así, en evidente referencia a los cristianos, que tienen que enfrentarse a los procedimientos sumamente expeditivos de los arrendadores hebreos, se dice: "e tienen para esto judíos muy sabidos/ para sacar los pechos e los nuevos pedidos;/ non lo dexan por lágrimas que oyan, nin gemidos”. 
torno a la Hacienda regia", cuya existencia es indudable, aunque resulta "imposible desentrañar y cuantificar con detalle a falta de datos" ${ }^{26}$. Evidentemente, esta situación contribuía a excitar aún más los ánimos contra los arrendadores judíos.

Unos arrendadores judíos que ya en la última centuria del Medievo tuvieron que compartir el oficio con los cristianos nuevos. En efecto, durante el siglo XV las conversiones masivas de judíos al cristianismo, escalonadas entre los primeros años de esa centuria y los momentos finales de la anterior ${ }^{27}$, hicieron que las filas de los arrendadores de rentas se poblaran de judeoconversos. Unos arrendadores judeoconversos que mantuvieron el legado profesional de sus antepasados judíos, perseverando en el ejercicio de una actividad económica que podía resultar muy rentable, pero que también tenía sus riesgos.

Evidentemente, buena parte de esos arrendadores judeoconversos se dejaron llevar por una inercia que no sólo tuvo consecuencias profesionales. Como es bien sabido, los recién llegados a las filas del cristianismo dieron ese paso desde el patente afán de evitar cambios drásticos en lo que había sido su vida hasta ese momento, si se prescinde de ese cambio trascendental que fue recibir el Bautismo ${ }^{28}$. Así, los cristianos nuevos conservaron habitualmente sus domicilios, aunque eso implicara, con harta frecuencia, el seguir conviviendo estrechamente con sus antiguos correligionarios ${ }^{29}$, con los que las relaciones fueron a veces complicadas, aunque también es cierto que en muchos casos esas relaciones fueron cordiales ${ }^{30}$. Igualmente, fue habitual que no renunciaran a los vínculos familiares con aquellos de sus parientes que optaron por mantenerse fieles a la fe de sus mayores ${ }^{31}$.

En estas circunstancias, parece bastante lógico que también mantuvieran las profesiones que habían ejercido antes de su conversión al cristianismo, profesiones

${ }^{26}$ Ladero Quesada, M. A.: Fiscalidad y poder real..., p. 258.

27 Sobre las mismas, consultar Mitre Fernández, E.: Los judios de Castilla.... Para estudiar las consecuencias que el Bautizo tuvo para los convertidos y para sus descendientes, ver RÁBADE OBRADó, M. P.: "Los judeoconversos en tiempos de Isabel la Católica", en VAldeón BAruQue, J. (ed.): Sociedad y economía en tiempos de Isabel la Católica, Valladolid, 2002, pp. 201-228, así como RÁBADE OBRADÓ, M. P.: "'Cristianos nuevos"”, en LADERo QuesadA, M. A. (coord.): El mundo social de Isabel la Católica: la sociedad castellana a finales del siglo XV, Madrid, 2004, pp. 275-292 (también en Medievalismo, 13-14 (2004), pp. 275-292).

${ }^{28}$ Cambio trascendental que a veces se quedó tan sólo en la superficie, habida cuenta de la gran cantidad de judeoconversos que siguieron practicando los ritos y ceremonias del judaísmo. Sobre esta cuestión existe una amplia bibliografía, citada por LADERo QueSADA, M. A.: "Grupos marginales", en La Historia Medieval en España: un balance historiográfico (1968-1998), Pamplona, 1999, pp. 505-601.

${ }^{29}$ Esa estrecha convivencia acabó siendo considerada muy perniciosa para los conversos, pues era opinión generalizada que favorecía el criptojudaísmo; por ese motivo, se decidió, corriendo el año 1480, proceder al apartamiento de los judíos, aunque lo cierto es que en muchas localidades no se llegó a hacer realidad. Sobre esta cuestión, ver SuÁrez FernÁndez, L.: La expulsión de los judios de España, Madrid, 1991.

${ }^{30}$ Sobre las relaciones entre judíos y cristianos, RÁBADE OBRAdó, M. P.: "Ser judeoconverso en torno a 1492", Kalakorikos 8 (Calahorra) 10 (2005) 37-56, concretamente pp. 51-52.

${ }^{31}$ Véase, por ejemplo, el caso de Diego Arias de Ávila, contador mayor de cuentas de Enrique IV, y de su segunda esposa, también de origen judío, Elvira González, sobre el que se recogen muchos testimonios en Carrete Parrondo, C.: Fontes Iudaeorum Regni Castellae. III: Proceso inquisitorial contra los Arias Dávila segovianos, un enfrentamiento social entre judios y cristianos, Salamanca, 1986. 
que, como era frecuente en ese momento, heredaron muchas veces sus hijos ${ }^{32}$. Los arrendadores judeoconversos se convirtieron, por tanto, en una realidad habitual, consagrándose al arrendamiento de toda clase de rentas, y convirtiendo esa situación en "algo así como una afición habitual" 33 . Por supuesto, una afición compartida, tanto con cristianos viejos como con judíos, pues unos y otros se dedicaban, también, al arrendamiento de rentas.

Una afición a la que, en opinión de sus coetáneos, dedicaban demasiado tiempo y demasiados afanes, que debían haber dedicado a otros menesteres más provechosos; así, en relación con la nueva oleada de conversiones que acompañó al decreto de expulsión de los judíos de 1492, los Reyes Católicos promulgaron, ya en 1493, una pragmática por la que se prohibía a los recientemente convertidos arrendar rentas, pues así podrían gozar de más tiempo libre para ocuparse de un negocio mucho más importante: la salvación de sus almas ${ }^{34}$.

\section{LA ACTUACIÓN DE LOS JUDEOCONVERSOS COMO ARRENDADO- RES DE RENTAS: ALGUNOS EJEMPLOS}

Los arrendadores judeoconversos, tal como ya se ha adelantado más arriba, tomaron todo tipo de rentas: reales, concejiles, señoriales y de la Iglesia, tal como demuestra la documentación, siempre en función de sus intereses y de sus posibilidades. Así, por ejemplo, sucedía con los judeoconversos de la ciudad de Jaén que se dedicaban a estos menesteres. Veamos algunos ejemplos, vinculados, precisamente, con dicha localidad.

Empecemos por las rentas reales: Fernando de Andújar, cambiador, debió dedicarse a negocios muy prósperos, pues era uno de los financieros más destacados de Jaén, pero la escasez documental con que se encuentra cualquiera que desee reconstruir su peripecia vital impide ir más allá de saber que arrendó en alguna ocasión la alcabala y treintena de los paños de la localidad ${ }^{35}$. Por su parte, Ruy Díaz de Jaén arrendó, entre

${ }^{32}$ Acerca de esta cuestión, consultar RÁBADE ObRadó, M. P.: "Ser judeoconverso...", pp. 47 y ss.

${ }^{33}$ Son palabras de Porras Arboledas, P. A.: Comercio, banca y judeoconversos en Jaén, 14751540, Jaén, 1993, p. 171.

${ }^{34}$ Esta prohibición, en principio vinculada con un plazo de tres años, fue renovándose periódicamente. Algunos judeoconversos hubieron de enfrentarse a duras penas por contravenirla, pero también hubo excepciones, pues los soberanos concedieron licencias para que de forma individual o colectiva diversos conversos pudieran sortear la prohibición; sobre esta cuestión, ver RÁBADE OBRADÓ, M. P.: "Más que una frontera: los judíos españoles y la raya de Portugal entre 1492 y 1500”, en GonZÁLEZ JiMÉNEZ, M., y Montes Romero Camacho, I. (eds.): La Península Ibérica entre el Mediterráneo y el Atlántico, siglos XIII-XV, Sevilla-Cádiz, 2006, pp. 597-606, y en concreto pp. 605-606. López Beltrán, M. T.: "Redes familiares y movilidad social en el negocio de la renta: el tándem Fernando de Córdoba-Rodrigo Álvarez de Madrid y los judeoconversos de Málaga", Revista del Centro de Estudios Históricos de Granada y su Reino (Granada) 2012 33-72, ha puesto una de esas renovaciones, concretamente la de 1496, en relación con la "estrepitosa quiebra" de uno de esos recientes conversos dedicado al arrendamiento de rentas, Fernando de Sosa (p. 43).

${ }^{35}$ Ibidem, p. 46. 
1477 y 1511 , numerosas rentas reales, entre ellas las del diezmo y medio diezmo de lo morisco y lo castellano ${ }^{36}$.

Entre los que arrendaron rentas concejiles, Fernando Pérez de Jaén, que corriendo el año 1514 arrendaba el abasto de la carne ${ }^{37}$. Sigamos con las rentas señoriales: Alfonso Alvín, de profesión curtidor, era arrendador habitual de rentas vinculadas con su ejercicio profesional, como la renta de las tenerías de Jaén, que pertenecían al señor de Villardompardo ${ }^{38}$. También pertenecía al señor de Villardompardo la almona del Jabón, arrendada en alguna ocasión por Fernando de Baeza ${ }^{39}$. Finalmente, las rentas vinculadas con la Iglesia, como las derivadas del arrendamiento de la dehesa de Víboras, en las proximidades de Jaén, que pertenecía a la orden de Calatrava y que fue arrendada en algún momento por Diego González ${ }^{40}$.

Por supuesto, ni qué decir tiene que fue habitual que no existiera una especialización en el arrendamiento de un tipo concreto de rentas: se arrendaba lo que se podía, y cuando se podía. Así, por ejemplo, Pedro de Úbeda arrendaba al mismo tiempo en el Jaén de 1485 la renta de la veintena de la madera, que era municipal, y la del diezmo del barro, que pertenecía a los señores de Villardompardo ${ }^{41}$.

Muchos de estos arrendadores judeoconversos no actuaron en solitario, si no que formaron compañías, lo que les permitía acceder a negocios más rentables, aunque también exigían un mayor desembolso económico inicial. Una vez más, podemos encontrar ejemplos en este sentido en la localidad de Jaén: en 1502, Lope de Baena se asoció con Lope de Jaén, Alonso Yáñez del Castillo y Gómez de Córdoba para arrendar la alcabala del hierro, el esparto y la especiería $a^{42}$. Por cierto, todos sus socios eran, también, judeoconversos. Por su parte, Alvaro de Cuéllar, que era vecino de Soria, y que arrendó diversas rentas en Cádiz y Sevilla durante la década de los noventa del siglo XV, formaba frecuentemente compañía con Juan de Haro, regidor de Ciudad Real, cristiano viejo, aunque casado con una conversa ${ }^{43}$. Un último ejemplo: Francisco de Mena, vecino de Aranda, arrendó diversas alcabalas y tercias de Calahorra y lugares de la merindad de Logroño formando compañía con el judío de Alfaro Mosen Abuzaque, precisamente pocos años antes de que se decretara la expulsión de los judíos ${ }^{44}$.

En muchos casos, los vínculos familiares resultaron esenciales de cara a la formación de estas compañías, que fueron capaces de desarrollar estrategias que les permitieron controlar porciones importantes del negocio fiscal. Un buen ejemplo es el del grupo liderado por Fernando de Córdoba y Rodrigo Álvarez de Madrid, que se articuló en torno a la ciudad de Málaga ${ }^{45}$. En torno a ellos se movía "un negocio de
${ }^{36}$ Ibidem, p. 92.
${ }^{37}$ Ibidem, p. 87.
${ }^{38}$ Ibidem, p. 44.
${ }^{39}$ Ibidem, p. 87.
${ }^{40}$ Ibidem, p. 97.
${ }^{41}$ Ibidem, p. 113.
${ }^{42}$ Ibidem, p. 53.
${ }^{43}$ Diago Hernando, M.: “Arrendadores arandinos...”, p. 82.
${ }^{44}$ Ibidem, p. 79.
${ }^{45}$ Dicho grupo ha sido estudiado por López Beltrán, M. T.: "Redes familiares...". 
arrendamiento enormemente intrincado por frecuentes pactos de negocio a partir de redes familiares y clientelares", en cuyo "entorno giraba toda una verdadera tela de araña de arrendadores medianos y pequeños" 46 .

Porque además con mucha frecuencia los arrendadores judeoconversos pertenecían a familias que estaban estrechamente vinculadas con ese oficio, existiendo una tradición que lo hacía pasar de padres a hijos. También, era habitual que varios miembros de una misma familia se consagraran, simultáneamente, al arrendamiento de rentas. Así sucedió, por ejemplo, con los hermanos madrileños Pedro y Luis de Villanueva. El segundo participó, en los años finales del siglo XV, en el arrendamiento de las rentas de los castellanos de los moros de Plasencia; el primero afrontó negocios de mayor importancia, pues formó compañía nada menos que con Fernán Núñez Coronel, para arrendar en el año 1498 toda una serie de rentas, vinculadas con el reino de Murcia, Lorca, obispado de Cartagena y marquesado de Villena, amén de otras en Jerez de la Frontera y su partido, así como en Carmona ${ }^{47}$.

Con cierta frecuencia, los arrendadores de rentas se vieron involucrados en pleitos y problemas como consecuencia de las irregularidades cometidas en virtud de su ejercicio profesional. Así, por ejemplo, el arandino Pedro de Santa Cruz arrendaba las rentas de la merindad de Santo Domingo de Silos, aunque al mismo tiempo era el escribano de rentas de dicha merindad, lo que estaba rigurosamente prohibido; aunque actuaba a través de persona interpuesta, fue descubierto, y tuvo bastantes conflictos por ese motivo ${ }^{48}$.

Los judeoconversos que arrendaron rentas pertenecían a un espectro social y económico de una cierta variedad. Entre ellos se contaban financieros en el sentido estricto del término (se pueden destacar casos como los de diversos miembros de la familia Arjona en Jaén, entre ellos Alonso Díaz de Arjona, Pedro Díaz de Arjona o Ruy Gómez de Arjona ${ }^{49}$ ), dedicados en exclusiva al arrendamiento de rentas, pero también artesanos y comerciantes enriquecidos, que dedicaban parte del capital acumulado a través de su ejercicio profesional al arrendamiento de rentas, siempre dentro de la medida de sus posibilidades; otra vez, Jaén puede ofrecernos algunos ejemplos significativos: Diego de Córdoba era uno de los más destacados comerciantes de Jaén en el tránsito del siglo XV al XVI ${ }^{50}$, mientras que Garci Fernández era cerero ${ }^{51}$, y Gonzalo de Herrera era curtidor ${ }^{52}$.

Fue realmente habitual que ostentaran oficios vinculados con la administración concejil, lo que demuestra, entre otras cosas, que se trataba de personas arraigadas en la vida política local, con todas sus consecuencias e implicaciones. Por ejemplo, Fernando Rodríguez Alegre fue mayordomo del concejo de Jaén durante los años

${ }^{46}$ En palabras de Carretero Zamora, J. M.: "Los arrendadores de la hacienda de Castilla a comienzos del siglo XVI (1517-1525)”, Studia Historica. Historia Moderna (Salamanca), 21 (1999) 153-190, concretamente p. 165.

${ }^{47}$ Rábade Obradó, M. P.: Orígenes del notariado madrileño: los escribanos públicos en el siglo $X V$, Madrid, 2001, p. 190.

${ }^{48}$ Ibidem, pp. 74-75

${ }^{49}$ Porras Arboledas,P. A.: Comercio, banca y judeoconversos..., pp. 51-52.

${ }^{50}$ Ibidem, p. 67.

${ }^{51}$ Ibidem, p. 77.

52 Ibidem, p. 81. 
iniciales del reinado de los Reyes Católicos ${ }^{53}$, mientras que Fernando Gómez de Córdoba desempeñó diversos oficios relacionados con la administración financiera de ese mismo concejo ${ }^{54}$. Muchos ejercían oficios de escribanía pública, pese a las prohibiciones que afectaban a la compaginación de tal oficio con el arrendamiento de rentas; entre ellos, el giennense Pedro Núñez de Soria ${ }^{55}$.

Asimismo, fue habitual que invirtieran parte de los beneficios obtenidos en sus operaciones financieras en la compra de bienes inmuebles, sobre todo heredamientos, quizá porque por esa vía consideraban que estaban legitimando el estatus social y económico alcanzado a través de su actividad financiera, también en un evidente intento por asemejarse a la nobleza, cuyos ideales y modos de vida muchas veces acabaron imitando. Por ejemplo, Pedro de Santa Cruz poseía en Aranda, aparte de las casas principales en las que moraba, otras diez casas más; además, diversas casas y huertas en lugares próximos a la localidad, así como viñas y tierras de pan llevar, uniéndose a todos estos bienes las casas y heredad que tenían en Salas de Barbadillo ${ }^{56}$.

Algunos de los judeoconversos dedicados al arrendamiento de rentas lograron ascender a la hidalguía, como sucedió con los Fernández de Baeza en Jaén, que en 1524 ya habían logrado el reconocimiento de su hidalguía, pese a que sus orígenes conversos eran bien conocidos en la localidad. Aunque la familia había contado con diversos miembros involucrados en el arrendamiento de rentas, entre ellos destacó especialmente el joyero Gonzalo Fernández de Baeza, que tomó, indistintamente, rentas reales y concejiles ${ }^{57}$.

Junto a los que lograron medrar gracias al arrendamiento de rentas, tanto desde el punto de vista económico como desde el punto de vista social, los que vieron truncadas esas ilusiones. En algunos casos, porque los negocios no les fueron bien, tal como le sucedió a Alonso Fernández de Jaén, obligado a huir de su ciudad natal por las deudas que había acumulado durante el ejercicio de su profesión ${ }^{58}$.

Otros vieron truncadas sus expectativas por problemas con la Inquisición... o por el miedo a tenerlos. Así, cuando se estableció en Sevilla el primer tribunal inquisitorial, una de sus consecuencias fue la huída de toda una serie de arrendadores, que prefirieron poner tierra de por medio antes que enfrentarse al Santo Oficio, quizá porque sabían que iban a salir derrotados de tal enfrentamiento ${ }^{59}$.

Entre ellos, Luis Sánchez y Andrés Abarrox, arrendadores de la entrada del vino, así como Fernando de las Casas y su hijo, que arrendaban la otra mitad; Juan Jiménez Abenbono, arrendador de la renta de las varas; Diego de Úbeda, arrendador de la guarda de la alhóndiga... Junto a los que prefirieron ausentarse, los que optaron por quedarse, aunque las circunstancias acabaran demostrando que, quizá, no había sido la decisión más acertada; entre ellos, Pedro Núñez de Soria, protagonista de

\footnotetext{
${ }^{53}$ Porras Arboledas, P. A.: Comercio, banca y judeoconversos..., p. 114.

${ }^{54}$ Ibidem, p. 70.

${ }^{55}$ Ibidem, p. 104.

${ }^{56}$ Diago Hernando, M.: “Arrendadores arandinos...”, p. 85.

${ }^{57}$ Porras Arboledas, P. A.: Comercio, banca y judeoconversos..., pp. 4-56.

${ }^{58}$ Ibidem, p. 85.

${ }^{59}$ A esta cuestión se refiere GIL, J.: Los conversos y la Inquisición sevillana, 3 vols., Sevilla, 2000,
} vol. 2, pp. 133 y ss. 
una intensa actividad entre 1497 y 1522, que se cortó abruptamente cuando en esa segunda fecha fue condenado por la Inquisición ${ }^{60}$.

En cualquier caso, fueron muchos los arrendadores judeoconversos que se resintieron "económicamente por las actuaciones de la Inquisición", entre los que se cuentan los que trabajaron en el ámbito malagueño ${ }^{61}$; si la actuación inquisitorial implicó, en algunos casos, la ruina, e incluso la muerte en la hoguera, también es cierto que en otros tan sólo significó un bache temporal, como sucedió con buena parte de los arrendadores que trabajaban en Málaga y su entorno ${ }^{62}$.

Es posible que en más de una ocasión se tratara de usar el Santo Oficio para ajustar cuentas con los arrendadores conversos. Así, cuando el arandino Pedro de Santa Cruz rompió la compañía que le había unido con su convecino Rodrigo de Prado, vivió un tiempo preocupado porque éste le amenazaba con acusarle falsamente ante el Santo Oficio, si no le satisfacía una cantidad que consideraba que le adeudaba ${ }^{63}$.

Tal vez para acallar las sospechas que pudiera suscitar su ortodoxia, quizá simplemente para dejar una memoria de sí mismos digna de la posición social y económica alcanzada, algunos de los arrendadores de rentas conversos que lograron llegar más alto se esforzaron por mostrar su condición de fieles cristianos, así como por proyectar esa imagen hacia el futuro.

Entre ellos, Antón Fernández de Baeza, que cuando testó dispuso que se le enterrara en la parroquia de San Andrés de Jaén, contando su sepelio con el acompañamiento de las cofradías de San Francisco, San Pedro, San Antonio y Santo Domingo de los pastores; para perpetuar su memoria y tratar de asegurar la salvación de su alma, el testador ordenaba entregar 250 ovejas a las cofradías de San Francisco y San Antonio, que, a cambio, habrían de celebrar todos los años un aniversario sobre su sepultura ${ }^{64}$. Por su parte, Fernando de Córdoba se hizo enterrar en la capilla que había mandado construir en el convento de San Francisco de Málaga. La capilla estaba situada a la derecha, debajo del coro, y fue hermoseada con un retablo encargado en 1516 al francés Nicolás Tiller ${ }^{65}$.

Desafortunadamente, las demostraciones de adhesión al cristianismo no siempre eran suficientes para acallar las dudas que generaba la ortodoxia de los arrendadores judeoconversos. Además, y tal como ya se ha adelantado, su profesión hizo que compartieran con sus colegas judíos la hostilidad de los cristianos viejos. En estas circunstancias, las mismas acusaciones que antaño se habían lanzado contra los

${ }^{60}$ Porras Arboledas, P. A.: Comercio, banca y judeoconversos..., p. 105.

${ }^{61}$ Como recuerda López Beltrán, M. T.: "Redes familiares...", p. 53, que también recoge unas significativas palabras del conde de Tendilla, que a comienzos del siglo XVI afirmaba que "están los unos recaudadores presos por la Ynquisición y otros huydos". Precisamente fue uno de nuestros arrendadores judeoconversos, Rodrigo Álvarez de Madrid, uno de los encargados de negociar con la Corona las habilitaciones que afectaron a los conversos reconciliados o descendientes de condenados de diversos distritos inquisitoriales, entre los que se contaba el Reino de Granada, a comienzos del siglo XVI (pp. 65 y ss.)

${ }^{62}$ Ibidem, p. 61 y ss.

${ }^{63}$ Diago Hernando, M.: “Arrendadores arandinos...”, p. 73.

${ }^{64}$ Porras Arboledas, P. A.: Comercio, banca y judeoconversos ..., p. 55.

${ }^{65}$ López Beltrán, M.T.: "Redes familiares...”, p. 70. 
arrendadores hebreos empezaron a lanzarse también contra los judeoconversos, contribuyendo a debilitar una posición que nunca fue lo suficientemente sólida.

A veces, esas acusaciones tenían una cierta base: es evidente que nuestro viejo conocido Pedro de Aranda "trató sistemáticamente de enriquecerse a costa de los campesinos de la merindad de Santo Domingo de Silos, e incluso de los vecinos de Aranda, utilizando el aparato hacendístico de la monarquía en su propio provecho"66; sus manejos le permitieron atesorar una fortuna que hacia el año 1507 se puede cifrar en la no desdeñable cantidad de unos seis millones y medio de maravedíes, cantidad que adquiere aún mayor relieve si se tiene en cuenta que había partido de una posición económica muy modesta ${ }^{67}$.

\section{ELITES JUDEOCONVERSAS Y ARRENDAMIENTO DE RENTAS: EL CASO DE LOS CORONEL}

Por supuesto, entre los arrendadores de rentas judeoconversos se contaron varios que formaban parte de la elite del grupo, personas muy próximas a los propios soberanos, que gozaban de su confianza, y que arrendaban esencialmente rentas reales, obteniendo pingües beneficios; se trataba, sin duda, de los "arrendadores de primera fila del reino" ${ }^{68}$, que se encontraban entre los numerosos cristianos nuevos que rodeaban a los reyes, esos judeoconversos a los que se refiere, no sin asombro, el viajero alemán polaco Nicolás de Popielovo ${ }^{69}$.

Entre ellos ocuparon un lugar de especial preeminencia Fernán Pérez Coronel y Fernán Núñez Coronel $^{70}$, cuyas peripecias vitales son, además, especialmente ilustrativas de las circunstancias en las que se producía el tránsito del arrendador judío al arrendador converso, así como las consecuencias a las que ese paso podía dar lugar, pues ambos nacieron judíos, aunque acabaron sus días como cristianos.

\footnotetext{
${ }^{66}$ Diago Hernando, M.: “Arrendadores arandinos...”, p. 75.

${ }^{67}$ Ibidem, p. 85.

${ }^{68}$ Ibidem, p. 78.

${ }^{69}$ Ver García Mercadal, J.: Viajes de extranjeros por España y Portugal desde los tiempos más remotos hasta el siglo XVI, 2 vols., Madrid, 1951, vol. 1, p. 203, así como LADERo QueSADA, M. A.: "Nicolás de Popielovo, viajero por tierras hispánicas (1484-1485)", Iacobus (Sahagún) 9-10 (2000) 91120 (también en Ladero Quesada, Países y hombres de la Edad Media, Granada, 2007, pp. 321-364).

${ }^{70}$ Además de la bibliografía que se va a citar en las siguientes notas, véanse también los trabajos, por orden cronológico, de CARRete Parrondo C.: "La hacienda castellana de rabbi Meir Relamed (Fernán Núñez Coronel). Sefarad (Madrid) 37 (1977) 339-350; Carrete Parrondo, C.: "R. Abraham Seneor (Fernán Pérez Coronel): conjeturas tradicionales y realidad documental", Sefarad (Madrid) 46 (1986) 111-122; López Álvarez, A. M.: "Un documento inédito de 1494 sobre Abraham Seneor y rabí Meir Melamed", Sefarad (Madrid) 56 (1996) 173-188; Moreno Koch, Y.: "Diez años de actividad económica en el reinado de los Reyes Católicos: Rabí Meir Melamed (Fernán Núñez Coronel)", en Carrete Parrondo, C. y Meyuhas Ginio, A. (eds.): Creencias y culturas: cristianos, judios y musulmanes en la España medieval, Salamanca, 1998, pp. 159-168; GARCÍA CASAR, F.: "Nuevas noticias sobre los Seneor/ Coronel segovianos", en Moreno Koch, Y. e Izquierdo Benito, R. A. (eds.): Del pasado judio en los reinos medievales hispánicos. Afinidad y distanciamiento, Cuenca, 2005, pp. 135-146 y PeÑa Barroso, E. de la: "Firmas y rúbricas de judeoconversos de la compañía de arrendadores Coronel-Alcalá", Sefarad (Madrid) 71 (2011) 201-208.
} 
Fernán Pérez Coronel, antes Abrahem Seneor, y Fernán Núñez Coronel, primero Meir Melamed, eran suegro y yerno, avecindados ambos en Segovia. El primero se consagró al servicio a la Corona desde el reinado de Enrique IV, en cuyo equipo financiero estaba integrado ${ }^{71}$; aunque se desconoce su actitud durante la rebelión del infante Alfonso, todo apunta en el sentido de que debió inclinarse en su favor, o al menos eso hace pensar el hecho de que se adhiriera, desde el primer momento, al partido de la infanta Isabel, cuyo camino al trono contribuyó a allanar de forma evidente, entre otras cosas porque la futura reina se valió de sus buenos oficios para atraer a su parcialidad a personajes tan destacados como Andrés de Cabrera. Esos servicios convirtieron a Seneor en el personaje judío más influyente de la corte de los Reyes Católicos, contando, desde la década de los ochenta, con la ayuda incondicional de su yerno, Meir Melamed ${ }^{72}$.

Abrahem Seneor era ya un importante arrendador de rentas en la segunda mitad de la década de los sesenta: ya entre 1468 y 1469 consta como arrendador del servicio y montazgo, mientras que entre la primera de esas dos fechas y 1473 también lo fue de los diezmos de la mar de Castilla ${ }^{73}$. Parece evidente que durante la última década del reinado de Enrique IV Abrahem Seneor se convirtió en el más solvente de los financieros judíos de Castilla, gozando de una gran influencia. Sin embargo, da la impresión de que su relación con el soberano fue siempre distante, frente a la evidente sintonía que más adelante tuvo con los Reyes Católicos, y en especial con la soberana.

Esa sintonía se refleja en el proceso de engrandecimiento que experimentó el judío desde que subieron al trono Isabel y Fernando. A poco de iniciarse el reinado, a finales de 1476, se le nombró alguacil de la aljama mayor de los judíos de Segovia, su localidad de residencia, y en los albores de 1477 ya era juez, rabino y repartidor mayor de todas las aljamas de Castilla ${ }^{74}$; estos dos nombramientos le convirtieron en el líder indiscutible de la comunidad hebrea castellana.

Paralelamente, Seneor se había convertido en el financiero más destacado de la Castilla de su tiempo, por su condición de arrendador de las más importantes rentas, tanto reales como de otra índole: en las postrimerías de 1477 era receptor de hierbas y alcabalas de hierbas de la orden de Calatrava; en torno a esas mismas fechas, era, juntamente con el también judío Vidal Bienveniste, receptor mayor del servicio y montazgo de los ganados; de nuevo ambos hebreos juntos, actuaban en 1479 como arrendadores mayores del arzobispado de Toledo ${ }^{75} \ldots$

Si el primer lustro de gobierno de los Reyes Católicos fue muy provechoso para Abrahem Seneor, más aún lo fueron los siguientes, pues a lo largo de la década de los ochenta fue la cabeza visible de una compañía que monopolizó, literalmente, el arrendamiento de rentas de la Corona de Castilla. Una compañía de la que también formaban parte Abrahem Bienveniste, quizá pariente del hebreo del mismo apellido

71 Se documenta su presencia en la corte enriqueña al menos desde 1466; consultar RÁBADE OBRADÓ, M. P.: Los judeoconversos en la corte y en la época de los Reyes Católicos, Madrid, 1990, p. 589.

72 Idem.

73 Ladero Quesada, M. A.: La hacienda real..., p. 437.

74 RÁBAde Obradó, M. P.: Los judeoconversos en la corte..., p. 831.

75 Idem. 
con el que Seneor había trabajado de forma habitual durante la década anterior, Meir Melamed (que a partir de ese momento secundó sistemáticamente a su suegro en todas sus actividades financieras) y el único cristiano del grupo, Luis de Alcalá, que, eso sí, era de origen judío ${ }^{76}$.

La lista de rentas arrendadas durante dicha década es impresionante. Por ejemplo, en 1482 llevaban las rentas de la ciudad de Segovia, su tierra y diócesis, por un monto de dos millones y cien mil maravedíes; las alcabalas, tercias, pechos y derechos de Medina del Campo y su tierra por tres millones y 375.000 maravedíes; las alcabalas de Zamora y su tierra por dos millones y 540.000 maravedíes; las alcabalas de Toro y su tierra por un millón 218.000 maravedíes $^{77} \ldots$

La década terminó, además, con un nombramiento a favor de Seneor que tenía una evidente importancia, el de tesorero de la Santa Hermandad, fechado en Valencia, a 18 de marzo de $1488^{78}$. La década siguiente se inició como había terminado la anterior: con la compañía desarrollando una intensísima actividad, actividad que no dejaba de suscitar sospechas y resquemores; así, ya en 1488 se habían desatado ciertos rumores, e incluso se había llegado a acusar a Seneor y a sus compañeros de intrigas y conspiraciones contra otros posibles arrendadores, aunque esas acusaciones al final se quedaron en papel mojado ${ }^{79}$.

Fue también a comienzos de los noventa cuando la estrella de Meir Melamed empezó a brillar con luz propia. Juntamente con Luis de Alcalá, al que estaba unido por vínculos de amistad, aparte de los puramente financieros, protagonizó un experimento impulsado por los soberanos, con el objetivo de canalizar la satisfacción de las más importantes libranzas a través de un nuevo organismo, la receptoría y pagaduría general, de la que eran responsables, conjuntamente, el judío y el converso, tratándose de aprovechar al máximo la "experiencia financiera y capacidad para operar con grandes sumas" 80 de ambos, sin que esa responsabilidad supusiera, ni mucho menos, el fin de su actividad como arrendadores.

Indudablemente, la promulgación del decreto de expulsión de los judíos supuso un duro golpe para los miembros hebreos de la compañía. Todos ellos se vieron afectados por la política "tendente a fomentar las conversiones al cristianismo, en especial las de personajes o grupos dirigentes" que sostuvieron los Reyes Católicos en esas circunstancias, impulsada, entre otros motivos más evidentes, por el hecho de que "podían tener carácter ejemplarizante para sus correligionarios" ${ }^{81}$. Así, los

${ }^{76}$ Ibidem, p. 832.

${ }^{77}$ Idem.

78 Ibidem, p. 833.

79 Ibidem, p. 948.

${ }^{80}$ Ladero Quesada, M. A.: La hacienda real..., p. 56. También, Ladero Quesada, M. A.: "La receptoría y pagaduría general de la Hacienda regia castellana entre 1491 y 1494: de Rabí Meir Melamed a Fernán Núñez Coronel”, En la España Medieval (Madrid) 25 (2002) 425-506. Véase también ORTEGO Rico, P.: "Auge y caída de una gran compañía financiera en Castilla: Luís de Alcalá, rabí Mayr y la quiebra de la receptoría y pagaduría general de rentas (1477-1495)", en GARCía FERNÁNDEZ, E. y Vítores CASADO, I. (eds.): Tesoreros, "arrendadores" y financieros en los reinos hispánicos: la Corona de Castilla y el Reino de Navarra (siglos XIV-XVII), Madrid, 2012, pp. 101-122.

${ }^{81}$ Ladero Quesada, M. A.: "Coronel, 1492: de la aristocracia judía a la nobleza cristiana en la España de los Reyes Católicos", Boletín de la Real Academia de la Historia (Madrid) CC/1 (2003) 11- 
grandes financieros judíos, y entre ellos Abrahem Seneor y Meyr Melamed, se vieron sometidos a importantes presiones, que en su caso concreto también están relacionadas con el hecho de que "tenían en sus manos buena parte de los arrendamientos de rentas reales ordinarios", y además "desde 1491, la receptoría de dinero que debían de entregar muchos otros arrendadores para gestionar la pagaduría general de todos los oficiales de la corte, sueldos militares y demás gastos de personal y de otros géneros a que la hacienda regia debía hacer frente"; evidentemente, su exilio habría provocado "un gravísimo perjuicio en el funcionamiento de la administración monárquica" 82.

Al final, las presiones surtieron efecto, y ambos se bautizaron en el transcurso de una solemne ceremonia que se celebró en el monasterio de Guadalupe, el día quince de junio de 1492, con la asistencia de los propios soberanos, y con el cardenal Pedro González de Mendoza como posible oficiante; diversos familiares les acompañaron hasta la pila bautismal, y eso, unido al hecho de que Abrahem Seneor y Meir Melamed tomaron apellidos parcialmente diferentes, permitió el nacimiento de dos familias también diferentes, aunque unidas por múltiples lazos, no sólo de parentesco, si no también de afinidad ${ }^{83}$.

Tras su cristianización, tanto Fernán Pérez Coronel como Fernán Núñez Coronel continuaron su actividad como arrendadores, aunque su compañía hubo de prescindir de Bienveniste, que optó por el exilio. A ese obligado abandono se unió, muy pronto, el vacío dejado por la muerte de Fernán Pérez Coronel, así que la compañía se renovó, pasando a formar parte de ella dos de los hijos del fallecido, Juan Pérez Coronel e Iñigo López Coronel, que también pasaron a trabajar en la receptoría general ${ }^{84}$.

Pese a los cambios obligados, la compañía siguió dando muestras de lo que podemos calificar, sin temor a equivocarnos, de una auténtica voracidad arrendadora, que llegó a su culminación durante el año 1494, cuando sus miembros arrendaron rentas por un monto total de 91 millones y 368.347 , maravedíes, una cantidad realmente exorbitante ${ }^{85}$. Se ha calculado que entre el año 1491 y el 1494 la compañía gestionó "en torno al 90 por ciento de los ingresos líquidos ordinarios de la hacienda" 86 .

Pero justamente fue ese mismo año cuando se inició la imparable decadencia de la compañía, suscitada por las disensiones que habían empezado a surgir entre sus miembros, y que acabaron provocando un enfrentamiento entre los hijos de Fernán Pérez Coronel, por un lado, y los inseparables Fernán Núñez Coronel y Luis de Alcalá, por el otro. Si a eso se une el fracaso de la receptoría general y el hecho de que Núñez Coronel acabó enredándose en una auténtica madeja de pleitos, es fácil entender que al final la compañía se fuera al traste. Los problemas derivados de esta situación persiguieron a Núñez Coronel hasta su muerte en 1500, y terminaron con la supremacía financiera de su familia, aunque él siguió arrendando rentas hasta su fallecimiento, si bien se movió en un nivel mucho más modesto que el que había

24, concretamente p. 11 (también en Ladero Quesada, M. A.: Países y hombres..., pp. 433-453.

82 Ibidem, p. 12.

${ }^{83} \mathrm{Idem}$ ofrece una pormenorizada información sobre la ceremonia y sus principales consecuencias.

${ }^{84}$ RÁbade Obradó, M. P.: Los judeoconversos en la corte..., p. 834.

${ }^{85}$ Ibidem, p. 835.

${ }^{86}$ Ladero Quesada, M. A.: “Coronel, 1492...”, p. 12. 
caracterizado sus primeros años como arrendador, secundado por alguno de sus parientes, y señaladamente por su hijo Francisco ${ }^{87}$.

Pero no todo siguió igual para los antiguos judíos tras su conversión al cristianismo: sus vidas experimentaron muchos cambios, como no podía ser de otra manera. Todavía de una forma más evidente que antes, se vieron distinguidos por el favor regio, en especial Fernán Pérez Coronel, que incluso experimentó la integración en la nobleza. Es evidente que los soberanos trataban "de integrarle en un estrato social privilegiado -de nobleza local urbana- respetando su función profesional en el ámbito de las finanzas. Buscaban quizá dignificarle y dignificar su actividad profesional"\$8.

Esa integración en la nobleza de Fernán Pérez Coronel tiene un carácter indudablemente excepcional, y se obró por la vía de concederle "la posesión de un linaje antiguo que estaba vacante por extinción física de sus antiguos propietarios" $\$$. La correspondiente Ejecutoria de Hidalguía fue otorgada por los soberanos el 25 de julio de 1492, y se justificaba por los muchos servicios que el nuevo hidalgo había prestado a la Corona, extendiéndose el privilegio de hidalguía a todos sus descendientes, por vía masculina y femenina ${ }^{90}$.

Asimismo, Seneor fue honrado con la concesión de dos oficios vinculados con la corte: contador del príncipe Juan y miembro del consejo real ${ }^{91}$, muy posiblemente más honoríficos que otra cosa, debido a su muy avanzada edad ${ }^{92}$. Igualmente, obtuvo un regimiento de la ciudad de Segovia, con facultad para renunciarlo en su primogénito. La renuncia se efectuó con prontitud, pues Juan Pérez Coronel tomó posesión del regimiento el final del mes de marzo de 1493, momento para el que ya había fallecido su padre ${ }^{93}$.

En cuanto a Meyr Melamed, también gozó del favor de los soberanos después de su conversión al cristianismo. Habida cuenta de la avanzada edad de su suegro, parece evidente que se hizo cargo de las tareas que éste desempeñaba en el aparato financiero cortesano; además, recibió también un regimiento en la ciudad de Segovia ${ }^{94}$. Aunque él no fue integrado en la nobleza, sus descendientes sí que estaban destinados a gozar de ese privilegio, al serlo también de Fernán Pérez Coronel.

Aunque, tal como ya se ha adelantado, suegro y yerno continuaron dedicándose al arrendamiento de rentas después de su conversión, cierto es que su nueva condición religiosa, unida a su integración en la nobleza, implicaba la necesidad de introducir algunos cambios en consonancia con tales novedades. Esos cambios fueron impulsados por los propios soberanos, que gratificaron a ambos con generosas cantidades en metálico destinadas a la compra de heredades: Pérez Coronel recibió la muy considerable cantidad de un millón 250.000 maravedíes, mientras que a su

${ }^{87}$ RÁbade Obradó, M. P.: Los judeoconversos en la corte..., pp. 835-836.

${ }^{88}$ Consultar Asenjo GonzÁlez, M.: Segovia: la ciudad y su tierra a fines del Medievo, Segovia 1986, p. 396.

${ }^{89}$ Ladero Quesada, M. A.: “Coronel, 1492...”, pp. 14-15.

${ }^{90}$ Editada y estudiada en Ibidem, pp. 11-24.

91 RÁbade Obradó, M. P.: Los judeoconversos en la corte..., p. 591.

${ }^{92}$ Como indica Ladero Quesada, M. A.: "Coronel, 1492...,", p. 17.

${ }^{93}$ Rábade Obradó, M. P.: Los judeoconversos en la corte..., p. 591.

${ }^{94}$ Idem. 
yerno se le entregaron 750.000 maravedíes $^{95}$. Evidentemente, los antiguos judíos tenían un escaso patrimonio inmueble, que los soberanos consideraban que debían de incrementar, y estaban dispuestos a ayudarles, pese a que esa ayuda parecía innecesaria, habida cuenta de la importante liquidez monetaria de la que disfrutaban $\operatorname{ambos}^{96}$.

Para sancionar de forma definitiva su conversión, sólo quedaba dar un último paso: proceder a la fundación de una capilla en alguna institución religiosa de prestigio en la ciudad donde los Coronel estaban avecindados, Segovia. Fue el propio Fernán Pérez Coronel el que tomó esa iniciativa, fundando una capilla sepulcral en el monasterio del Parral, bajo la significativa advocación de la Santa $\mathrm{Cruz}^{97}$. En virtud de su testamento, Coronel dotó a la capilla con un juro de heredad de 10.000 maravedíes anuales, a la par que establecía múltiples oficios divinos en sufragio de su alma, sin olvidar tampoco a sus allegados ${ }^{98}$. Como es evidente, se trataba de una capilla que no sólo estaba destinada a albergar el sueño eterno de su fundador, si no también a facilitar la definitiva inserción de su familia en el seno de la sociedad cristiana.

Pero el "triunfo" de los Coronel resultó efímero: primero, las rencillas que ya desde el año 1494 separaron a las dos ramas familiares, $y$, después, su participación en las Comunidades, terminaron con su rápido ascenso. Sobre todo, fue especialmente negativa para el progreso del linaje la actuación en las Comunidades de uno de sus más importantes miembros durante las décadas iniciales del siglo XVI, Iñigo López Coronel. Éste, aparte de ser el suegro de uno de los principales dirigentes comuneros, Juan Bravo, que estaba casado con su única hija, participó además activamente en el conflicto, lo que le acarreó serios problemas, aunque tampoco conviene exagerar las cosas, pues, pese a todo, la familia conservó una sólida implantación a nivel local en la ciudad de Segovia, y, ocasionalmente, algunos de sus miembros lograron reverdecer los laureles familiares, accediendo a la confianza regia, tal como había sido habitual en algunos de sus ancestros; así sucedió con los hermanos Luis y Antonio Núñez Coronel, muy próximos al Emperador ${ }^{99}$.

Una buena demostración de que, pese a todo, la familia siguió gozando de relevancia, al menos a nivel local segoviano, es el hecho de que, ya durante la Edad Moderna, procediera a elaborar una falsa genealogía, en el afán de ocultar sus orígenes judíos, trocándolos en cristianos limpios. Este fantasioso viaje a través de los antepasados de los Coronel consta en el traslado que, andando 1781, se hizo de su Ejecutoria de Hidalguía, concedida por los Reyes Católicos al iniciador del linaje, Fernán Pérez Coronel, otrora Abrahem Seneor ${ }^{100}$.

Esa supuesta genealogía de la familia Coronel se vale de la coincidencia de apellidos con una familia originaria de Medina del Campo, aunque instalada en Sevilla desde

95 Ibidem, p. 907.

${ }^{6}$ Sobre esta cuestión, véase, PeÑa Barroso E. de la: "Las propiedades rústicas de uan familia de conversos segovianos: los Seneor/Coronel", Espacio, Tiempo y Forma (serie III: Historia Medieval) (Madrid) 24 (2011) 319-352.

${ }^{97}$ Hernando, T.: "Luís y Antonio Núñez Coronel”, Estudios Segovianos (Segovia) XXI (1969) 385 422, p. concretamente p. 390.

98 Asenjo González, M: Segovia ..., p. 397.

99 Véanse las palabras que les dedica Hernando, T.: "Luís y Antonio Núñez Coronel".

${ }^{100}$ Ibidem, p. 389 y ss. 
los tiempos de Alfonso XI, para asegurar tajantemente la existencia de un parentesco cercano entre ambos linajes. La historia del linaje se trazaría, así, desde esos supuestos antepasados cristianos viejos hasta Alfonso Fernández Coronel, que sería el padre de Fernán Pérez Coronel, de cuya condición originaria de judío nada se menciona. Esta falsa genealogía, que quizá empezó a fraguarse ya en la década de los veinte del siglo XVI ${ }^{101}$, parece que fue aceptada por los coetáneos de los descendientes de los Coronel, como demuestra el hecho de que precisamente el descendiente del linaje que propició la realización del traslado de la Ejecutoria de Hidalguía fuera, entre otras cosas, familiar de la Inquisición de Córdoba, de modo que debía haber superado las correspondientes pruebas de limpieza de sangre ${ }^{102}$.

\section{CONCLUSIONES}

Los judeoconversos jugaron un papel esencial en el arrendamiento de rentas durante el reinado de los Reyes Católicos. De entre ellos destacan aquellos que estaban vinculados con las elites cortesanas, que gozaban de la confianza y proximidad de los monarcas. Estos financieros conversos no se limitaron a actuar como arrendadores de rentas de gran cuantía económica, si no que también colaboraron con los Reyes Católicos desempeñando diversos cargos de índole financiera, vinculados a veces con experiencias que pretendían mejorar la gestión de la hacienda regia ${ }^{103}$.

Sus aventuras financieras, unidas al servicio a la Corona, no sólo les depararon un evidente enriquecimiento, pues, igualmente, obtuvieron gracias a ellas algunos señalados favores de los soberanos, que contribuyeron a consolidar su posición social, e incluso en algún caso extremo les permitieron ingresar en las filas de la nobleza.

Ese fue el caso de los Coronel, ennoblecidos como consecuencia de su conversión al cristianismo, protagonistas de una plena integración en las filas de la nobleza, si bien es cierto que para sancionar ese proceso se vieron obligados a renunciar a sus orígenes judíos, pues las nuevas circunstancias de la España del siglo XVI les impulsaron a elaborar una falsa genealogía, que les convertía en cristianos viejos, alejando cualquier sospecha sobre su ortodoxia religiosa, y evitando las consecuencias negativas de los ya muy generalizados Estatutos de Limpieza de Sangre.

Quizá, la trayectoria de los Coronel pueda ejemplificar las aspiraciones de muchos de los arrendadores conversos del reinado de los Reyes Católicos: "apellidos y armas, hidalguía, oficio público, heredamientos, capilla funeraria"104. Una trayectoria que estuvo al alcance de muy pocos, y que, aún cuando se lograba completar, no estuvo exenta de renuncias y sinsabores

101 Tal como afirma Ladero Quesada, M. A..: “Coronel, 1492...”, p. 19.

${ }^{102}$ Hecho que, por cierto, no era totalmente inhabitual en estos casos, debido a la frecuencia con la que los conversos procedían a la invención de falsas genealogías; sobre esta cuestión, véase RÁBADE OBRADÓ, M. P.: "La invención como necesidad: genealogía y judeoconversos", en LADERo QuesADA, M. A.: (coord.), Estudios de Genealogía, Heráldica y Nobiliaria. En la España Medieval: anejos, Madrid, 2006, pp. 183-201.

${ }^{103}$ A ellas se refiere LAdero QuesadA, M. A.: La hacienda real....

104 Ladero Quesada, M. A.: “Coronel, 1492...,", p. 18. 